\title{
STUDENTS OF THE FACULTY OF EDUCATION AND THEIR VIEW ON THE USE OF ELECTRONIC STUDY MATERIALS
}

Miroslav CHRÁSKA*, Univerzita Palackého v Olomouci, Česká republika

Přijato: 2. 5. 2016 / Akceptováno: 25. 7. 2016

Typ článku: Výzkumná studie

DOI: $10.5507 /$ jtie.2016.024

Abstract: The article presents the results of a comparative research study performed at the Faculty of Education, Palacky University Olomouc, which involved first grade students. The research was aimed at various types of information resources the students use during their study including their opinion about electronic study materials. We used a cluster analysis to investigate typical groups of students in the research sample according to their use of and approach to electronic study materials. A total of three groups of students were identified that have completely different approaches to using information resources. The article was a part of an project IGA_PdF_2015_009.

Key words: university student, electronic study materials, traditional printed study materials, cluster analysis, comparative research.

\section{STUDENTI PEDAGOGICKÉ FAKULTY A JEJICH POHLED NA VYUŽITÍ ELEKTRONICKÝCH STUDIJNÍCH MATERIÁLŮ}

Abstrakt: Článek předkládá výsledky komparativního výzkumu realizovaného na Pedagogické fakultě UP v Olomouci u studentů prvnich ročníkü. Výzkumné šetřeni se opakovaně zabývalo tím, jaké informační zdroje studenti během studia uživaji, a to včetně jejich pohledu na elektronické studijni opory. Pomocí shlukové analýzy bylo zkoumáno, jaké typické skupiny studentů podle způsobu využití a př́stupu k elektronickým studijním oporám i ke klasickým studijním materiálům se ve zkoumaném vzorku vyskytuji. Celkově byly identifikovány tři skupiny studentů, které maji zcela rozdilné př́stupy $k$ využivání informačnich zdrojů. Př́spěvek vznikl v rámci řešeni projektu IGA_PdF_2015_009.

Klíčová slova: vysokoškolský student, elektronické studijní materiály, tradiční tištěné studijní materiály, shluková analýza, srovnávací výzkum.

*Autor pro korespondenci: miroslav.chraska@upol.cz 


\section{1 Úvod}

V souvislosti se stále větším využiváním elektronických studijních materiálů, či celých elektronických výukových kurzů, se stále více začíná analyzovat proces vlastního učení studentů v tomto výukovém prostředí a způsob jejich „průchodu“ vzdělávacím kurzem.

Při zpracování výzkumných dat, které jsou o procesu učení dostupné z LMS systémů, se používají metody Educational data mining a Learning analytics (Siemens, 2012a; Siemens, Baker, 2012b) pro analýzu učení a výuky v e-learningovém systému. Jako př́íklad z domácího prostř̌edí můžeme uvést identifikaci čtyř základních typů interakcí v on-line diskuzích v elektronických kurzech (Juhaňák, Zounek, 2015). Identifikován byl: typ A (žádná interakce), typ B (nízká interakce) typ C (interakce ve tvaru hvězdy), typ $\mathrm{D}$ (intenzivní interakce) s přibližně rovnoměrným rozložením četností.

Dříve provedené výzkumy procesu učení také ukázaly, že studenti mají tendenci se učit různými způsoby a chtějí raději používat různé prostředky učení. Mnozí se shodují na tom, že učební materiály by měly nejen odrážet styl učitele, ale měly by být navrženy pro všechny druhy studentů a všechny typy stylů učení (Šarmanová, Kostolányová, 2015). Ukazuje se také, že postoje studentů k realizaci vzdělávání formou e-learningu mohou být u různých skupin studentů odlišné (Klement, Chráska, Chrásková, 2015).

S pokračujícím růstem podpory on-line učení a využíváním nových technologií pro sběr velkého množství dat o průběhu vzdělávací činnosti lze $\mathrm{v}$ budoucnu očekávat velký zájem o tuto oblast. Dá se předpokládat, že začnou být detailněji analyzovány i masivní on-line otevřené kurzy (MOOC) u poskytovatelů jako jsou Coursera, edX a Udacity.

\section{Cíle a metody výzkumu}

\subsection{Cíle výzkumu}

Hlavním cílem výzkumného šetření, které bylo provedeno na podzim roku 2015 na Pedagogické fakultě Univerzity Palackého v Olomouci, bylo zjistit, jakým způsobem studenti pracují s různými informačními zdroji a jaké studijní materiály osobně preferují. Zda upřednostňují učení spíše pomocí klasických tištěných studijních materiálů nebo pomocí elektronických studijních opor a zda se tato preference odlišuje podle jejich studijního zaměření. Zjištováno také bylo, zda studenti, oproti roku 2013, více využívají elektronické studijní opory a zda jsou s nimi spokojeni. Dále byl výzkum zaměřen na to, jaké informační zdroje studenti, oproti roku 2013, používají při studiu a v jakém rozsahu.

Závěrečným cílem výzkumu bylo studenty, na základě jejich výpovědí, rozdělit do několika charakteristických skupin, které by s informačními zdroji pracovali odlišným způsobem.

\subsection{Použité výzkumné metody}

Jako výzkumná metoda pro sběr dat byl použit dotazník, konkrétně sestavený pro tyto účely a vycházející z obdobného dotazníku, který byl použit v roce 2013 (Janská, 2013; Chráska, 2014). Pomocí dotazníku byly zjišt’ovány následující proměnné, mající předpokládaný vztah ke způsobu práce s informačními zdroji a umožňující nám identifikovat príípadné typické charakteristiky skupin studentů. 
- Jaké informační zdroje studenti používají během studia a v jakém zastoupení (knihy, skripta, tisk, časopisy, vlastní poznámky, Internet, elektronické studijní opory, výukové programy na CD/DVD, e-learningový kurz, jiný zdroj).

- Znalost pojmu „Elektronické studijní materiály“.

- Zda se studenti setkali s elektronickými studijními materiály během studia na VŠ či SS̆.

- Spokojenost $\mathrm{s}$ elektronickými studijními materiály (měřená na škále 1-5, 1 nejmenší, 5 největší).

- Spokojenost s klasickými tištenými studijními materiály (opět na škále 1-5).

- Preference učení spíše pomocí klasických tištěných materiálů (knihy, skripta, tisk, ...) nebo pomocí elektronických studijních opor.

- Zda studenti chtějí dále ve svém studiu využívat elektronické studijní opory.

- Studijní zaměření, obor a forma studia.

- Pohlaví studenta.

\subsection{Popis výzkumného vzorku}

Výzkumný vzorek tvořilo 128 studentů, z toho 93 žen a 33 mužů (2 studenti své pohlaví neuvedli). Konkrétně se jednalo o studenty prvních ročníků prezenční i kombinované formy bakalářského studia následujících zaměření:

- Skupina T - studenti technického zaměření - studenti bakalářského studijního oboru Základy technických věd a informačních technologií pro vzdělávání a oboru Informační výchova se zaměřením na vzdělávání.

- Skupina $\mathrm{H}$ - studenti humanitního zaměření - studenti bakalářského studijního oboru Výchova ke zdraví se zaměřením na vzdělávání.

- Skupina K (kontrolní - studenti různého zaměření mimo výše uvedené obory Speciálněpedagogická andragogika a Učitelství pro mateřské školy.

Podrobnější strukturu výzkumného vzorku uvádí tab. č. 1. Studenti sledovaných skupin $\mathrm{T}$ a $\mathrm{H}$ měli přitom zhruba stejné možnosti využití e-learningových materiálů, které měli k dispozici v LMS systému UNIFOR, či v systému Courseware.

\begin{tabular}{|c|c|c|c|c|}
\hline Zaměření & Pohlaví (žena) & Pohlaví (muž) & Pohlaví (neuvedeno) & Celkem \\
\hline $\mathrm{T}$ & 19 & 14 & 0 & 33 \\
\hline $\mathrm{H}$ & 45 & 17 & 1 & 63 \\
\hline $\mathrm{K}$ & 29 & 2 & 1 & 32 \\
\hline Celkem & 93 & 33 & 2 & 128 \\
\hline
\end{tabular}

Tab. c. 1: Struktura výzkumného vzorku.

\subsection{Použité metody na zpracování výzkumu}

Ke zpracování dat $\mathrm{z}$ výzkumu byla primárně použita hierarchická shluková analýza, globalizovaná shluková analýza, analýza rozptylu, t-test a test nezávislosti chí-kvadrát (Meloun, Militký, Hill, 2005; Hendl, 2004). Všechny výpočty byly provedeny v prostředí statistického paketu STATISTICA 12. 


\section{Postup zpracování výsledků výzkumu}

V první části výzkumu bylo porovnáváno, jaké informační zdroje studenti používali během studia (a v jakém zastoupení) v roce 2013 a po dvou letech v roce 2015. Dále byla pomocí $\mathrm{t}$-testu porovnávána spokojenost $\mathrm{s}$ elektronickými a klasickými tištenými studijními materiály v roce 2013 a 2015 . Výsledky srovnání uvádí obr. 1-3 a tab. č. 2. Vzhledem k tomu, že do výzkumu v roce 2013 byli zahrnuti jen studenti prezenčního studia (dále jen PS), byly pro adekvátní srovnání v roce 2015 výsledky rozděleny pro studenty PS a studenty kombinované formy studia (dále jen KS).

\begin{tabular}{|l|c|c|c|}
\hline & Rok 2013 & Rok 2015 & Signifikance p \\
\hline $\begin{array}{l}\text { Spokojenost s elektronickými } \\
\text { studijními materiály (škála 1-5) }\end{array}$ & 3,39 & 3,45 & 0,32 \\
\hline $\begin{array}{l}\text { Spokojenost s klasickými tištenými } \\
\text { studijními materiály (škála 1-5) }\end{array}$ & $\mathbf{3 , 7 2}$ & $\mathbf{3 , 3 5}$ & $\mathbf{0 , 0 1}$ \\
\hline
\end{tabular}

Tab. č. 2: Spokojenost s elektronickými a klasickými tištěnými studijními materiály v roce 2013 a 2015.

V druhé části výzkumu bylo zjištováno, zda je odpovědi studentů možné rozdělit do několika typických skupin. Výše uvedené sledované proměnné byly pro adekvátní interpretaci dále standardizovány a byla provedena hierarchická shluková analýza.

Z výsledného dendrogramu (viz obr. č. 4) je možno identifikovat, že sledovaní studenti mají tendenci se seskupit do tří hlavních významných shluků (clusterů). Z výsledků shlukové analýzy je však patrné, že tytéž studenty můžeme (teoreticky) na hladině podobnosti 80 rozdělit i do pěti charakteristických skupin.

Proto byla se zkoumanými proměnnými provedena globalizovaná shluková analýza pro kontinuální a kategoriální proměnné a zároveň př̌i ní byla provedena verifikace počtu shluků - viz tab. č. 3. Souhrnné výsledky uvádí tab. č. 4 a 5. 


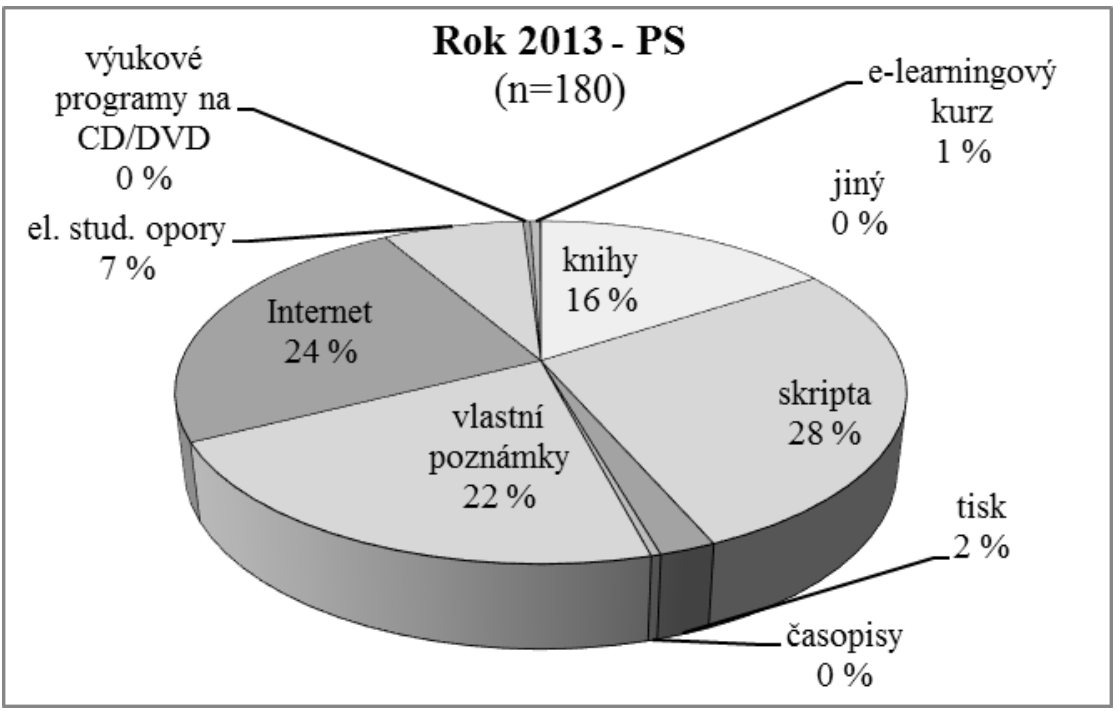

Obr. č. 1: Využití jednotlivých informačních zdrojů u studentů v prezenční formě studia (PS) na PdF UP v roce 2013.

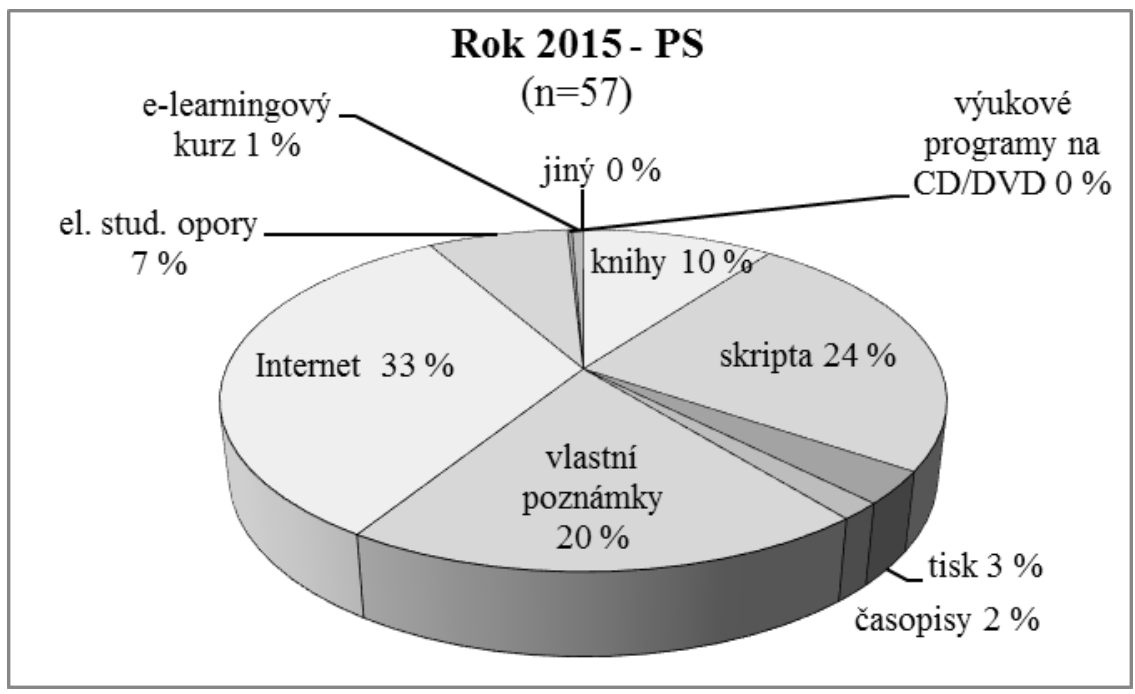

Obr. č. 2: Využití jednotlivých informačních zdrojů u studentů v prezenční formě studia (PS) na PdF UP v roce 2015. 


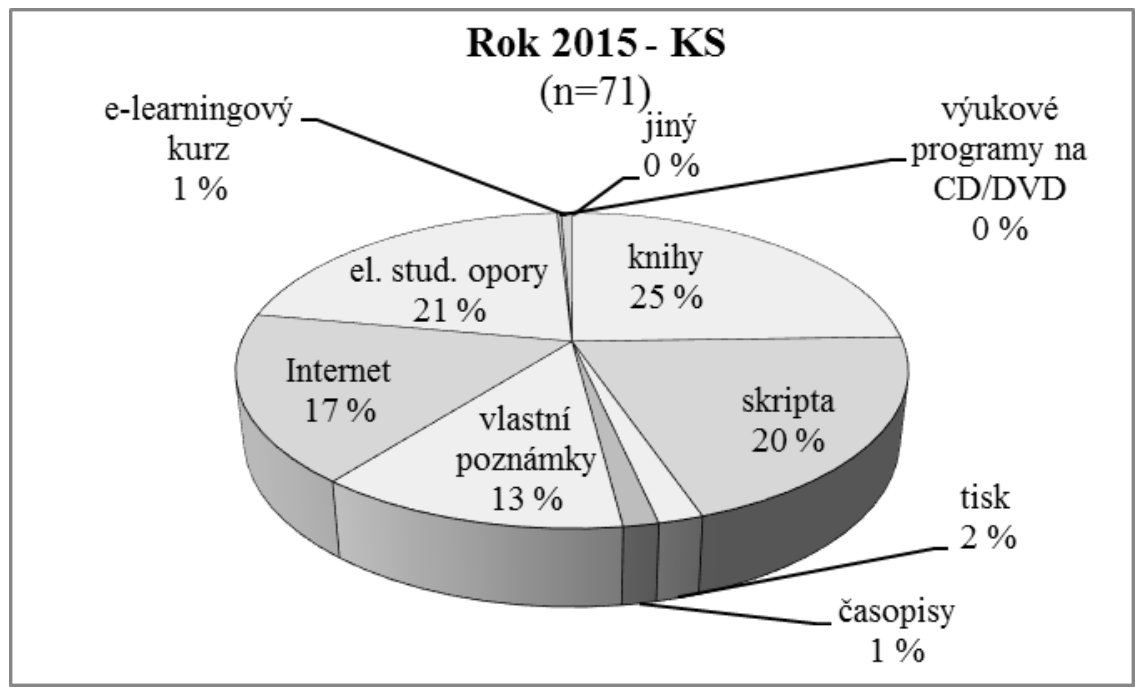

Obr. č. 3: Využití jednotlivých informačních zdrojů u studentů v kombinované formě studia $(K S)$ na PdF UP v roce 2015.

\begin{tabular}{|l|l|}
\hline & $\begin{array}{l}\text { Souhrn pro shlukování metodou K-means } \\
\text { Počet shluků: 3, Celkový počet prípadů: } 82\end{array}$ \\
\hline Algoritmus & k-Means \\
\hline Metoda pro měření vzdálenosti & Euclidean distances \\
\hline Výchozí centra & Maximize initial distance \\
\hline Vypuštění chybějících případů & Yes \\
\hline Kř́žová validace & 10 folds \\
\hline Zkušební vzorek & 0 \\
\hline Počet př́ípadů & 82 \\
\hline Chyba & 1,29 \\
\hline Určený počet shluků & 3 \\
\hline
\end{tabular}

Tab. č. 3: Globalizovaná shluková analýza - verifikace počtu shluků. 


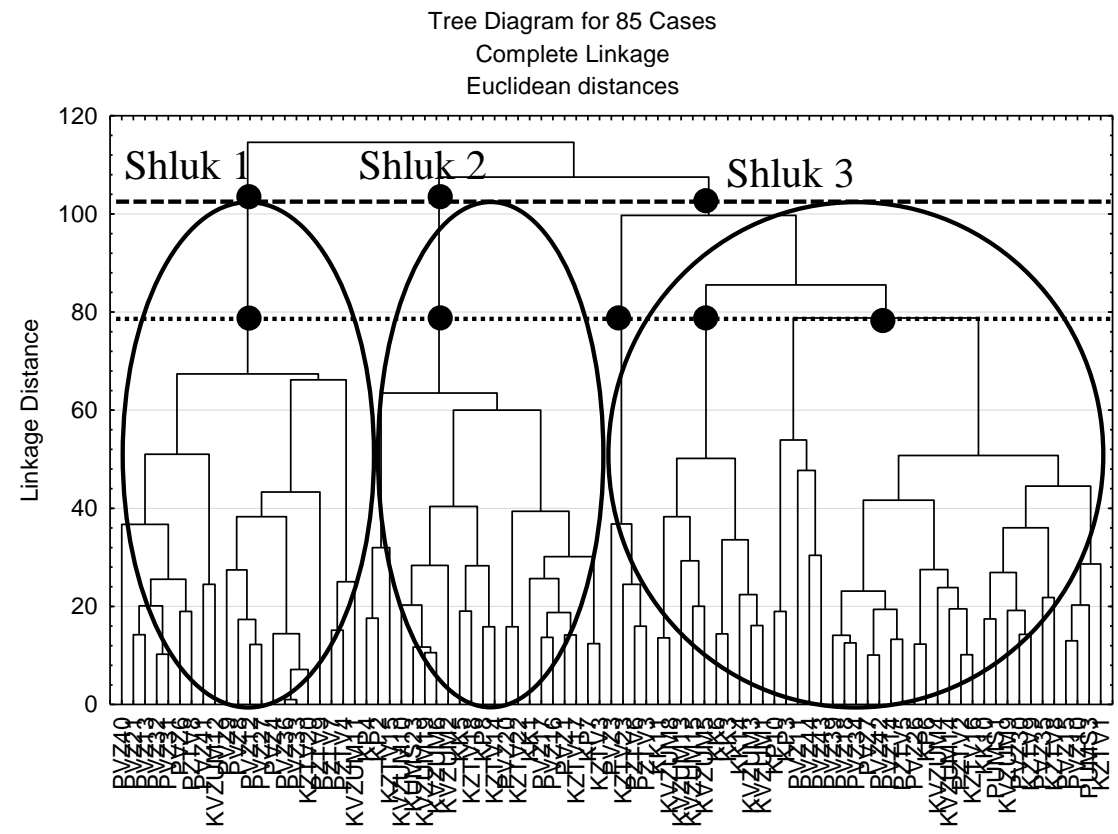

Obr. č. 4: Dendrogram shlukové analýzy - identifikace 3 shluků (skupin studentů).

Aby bylo možno lépe interpretovat výsledky globalizované shlukové analýzy uvedené souhrnně v tab. č. 6 pro všechny tři shluky, uvádíme dále $\mathrm{v}$ textu i grafické znázornění všech významně působících proměnných (graf č. 1-6). Z těchto grafü lze blíže analyzovat složení a typické vlastnosti jednotlivých identifikovaných shluků studentů. Dále by bylo možné uvést pro úplnost i členy jednotlivých identifikovaných shluků studentů tak, jak byly určeny v programu STATISTICA 12, avšak vzhledem $\mathrm{k}$ rozsahu príspěvku tak neučiníme. 


\begin{tabular}{|c|c|c|c|c|c|c|}
\hline \multirow[t]{2}{*}{ Kontinuální proměnná } & \multicolumn{6}{|c|}{$\begin{array}{l}\text { ANOVA pro kontinuální proměnné } \\
\text { Počet shluků: } 3 \text {, Počet případů: } 82\end{array}$} \\
\hline & $\begin{array}{c}\text { Mezi } \\
\text { skupinami } \\
\text { (SS) }\end{array}$ & $\mathrm{df}$ & $\begin{array}{l}\text { Uvnitř } \\
\text { skupin } \\
\text { (SS) }\end{array}$ & $\mathrm{df}$ & $\mathrm{F}$ & $\begin{array}{l}\text { Signifi- } \\
\text { kance } \\
\text { p }\end{array}$ \\
\hline Informační zdroj: knihy & 3249,09 & 2 & 15078,38 & 79 & 8,51 & 0,0004 \\
\hline Informační zdroj: skripta & 1470,44 & 2 & 13906,77 & 79 & 4,18 & 0,0188 \\
\hline Informační zdroj: tisk & 128,57 & 2 & 2199,92 & 79 & 2,31 & 0,1060 \\
\hline Informační zdroj: časopisy & 34,52 & 2 & 1861,74 & 79 & 0,73 & 0,4839 \\
\hline $\begin{array}{l}\text { Informační zdroj: vlastní } \\
\text { poznámky }\end{array}$ & 280,47 & 2 & 14097,09 & 79 & 0,79 & 0,4592 \\
\hline Informační zdroj: Internet & 6079,19 & 2 & 35754,33 & 79 & 6,72 & 0,0020 \\
\hline Inform. zdroj: el. stud. opory & 8034,45 & 2 & 17943,45 & 79 & 17,69 & $<0,0001$ \\
\hline $\begin{array}{l}\text { Informační zdroj: výukové } \\
\text { programy na CD/DVD }\end{array}$ & 1,91 & 2 & 123,57 & 79 & 0,61 & 0,5455 \\
\hline $\begin{array}{l}\text { Informační zdroj: e- } \\
\text { learningový kurz }\end{array}$ & 24,28 & 2 & 461,09 & 79 & 2,08 & 0,1316 \\
\hline $\begin{array}{l}\text { Spokojenost s el. stud. } \\
\text { materiály }\end{array}$ & 17,35 & 2 & 63,10 & 79 & 10,86 & $<0,0001$ \\
\hline $\begin{array}{l}\text { Spokojenost s klasickými } \\
\text { tištěnými studijními oporami }\end{array}$ & 3,18 & 2 & 97,12 & 79 & 1,30 & 0,2795 \\
\hline
\end{tabular}

Tab. č. 4: Zobecnèná shluková analýza pro kontinuálni proměnné.

\begin{tabular}{|c|c|c|c|c|c|}
\hline \multirow[t]{2}{*}{ Kategoriální proměnné } & \multicolumn{5}{|c|}{$\begin{array}{l}\text { Test nezávislosti pro kategoriální } \\
\text { proměnné, Počet shlukù: } 3 \\
\text { Celkový počet případů: } 82\end{array}$} \\
\hline & $\mathrm{df}$ & $\begin{array}{c}\text { Chí- } \\
\text { kvadrát }\end{array}$ & $\mathrm{p}$ & $\begin{array}{c}\text { G- } \\
\text { kvadrát }\end{array}$ & $\mathrm{p}$ \\
\hline Obor & 4 & 32,61 & $<0,0001$ & 36,83 & $<0,0001$ \\
\hline Forma studia & 2 & 39,14 & $<0,0001$ & 50,00 & $<0,0001$ \\
\hline $\begin{array}{l}\begin{array}{l}\text { Znáte pojem } \\
\text { materiály? }\end{array} \\
\end{array}$ & 2 & 1,42 & 0,4893 & 1,77 & 0,4110 \\
\hline $\begin{array}{l}\text { Setkali jste se s elektronickými stud. } \\
\text { materiály při studiu na VŠ (SŠ)? }\end{array}$ & 10 & 39,84 & $<0,0001$ & 42,76 & $<0,0001$ \\
\hline Preference učení z: & 8 & 42,67 & $<0,0001$ & 48,96 & $<0,0001$ \\
\hline $\begin{array}{l}\text { Chtěli byste dále ve studiu využívat } \\
\text { elektronické studijní opory? }\end{array}$ & 2 & 4,90 & 0,0859 & 6,63 & 0,0361 \\
\hline Pohlaví & 2 & 30,34 & $<0,0001$ & 30,97 & $<0,0001$ \\
\hline
\end{tabular}

Pozn.: Signifikantní rozdíly jsou označeny tučně a kurzívou.

Tab. č. 5: Zobecněná shluková analýza pro kategoriální proměnné. 


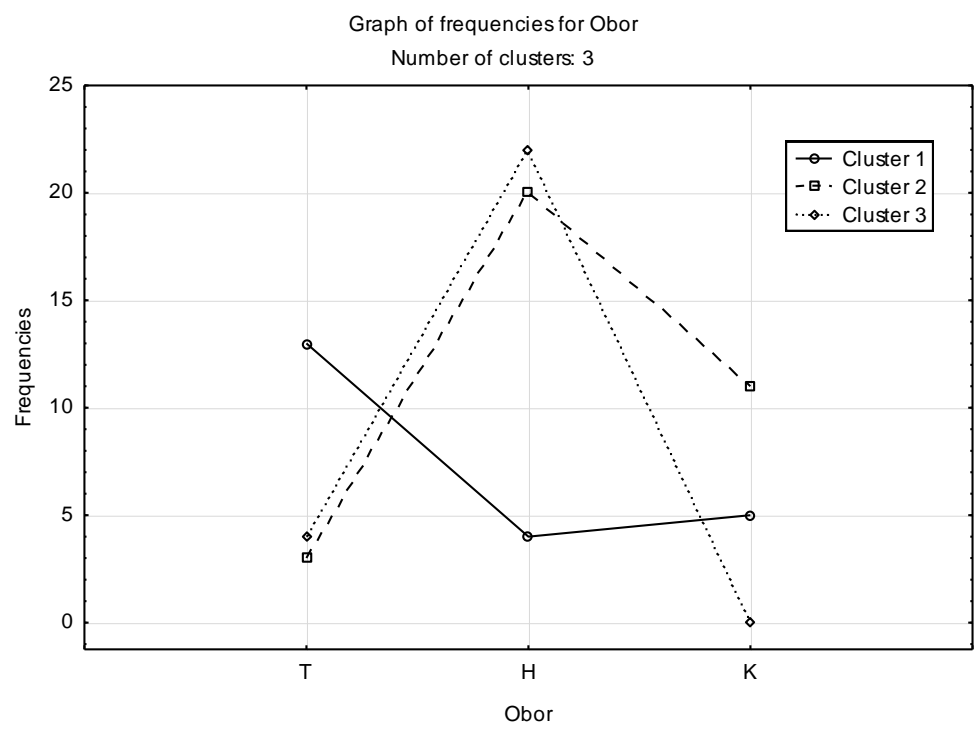

Graf č. 1: Analýza proměnné Obor podle př́slušnosti k jednotlivým shlukům.

Graph of frequencies for Forma studia

Number of clusters: 3

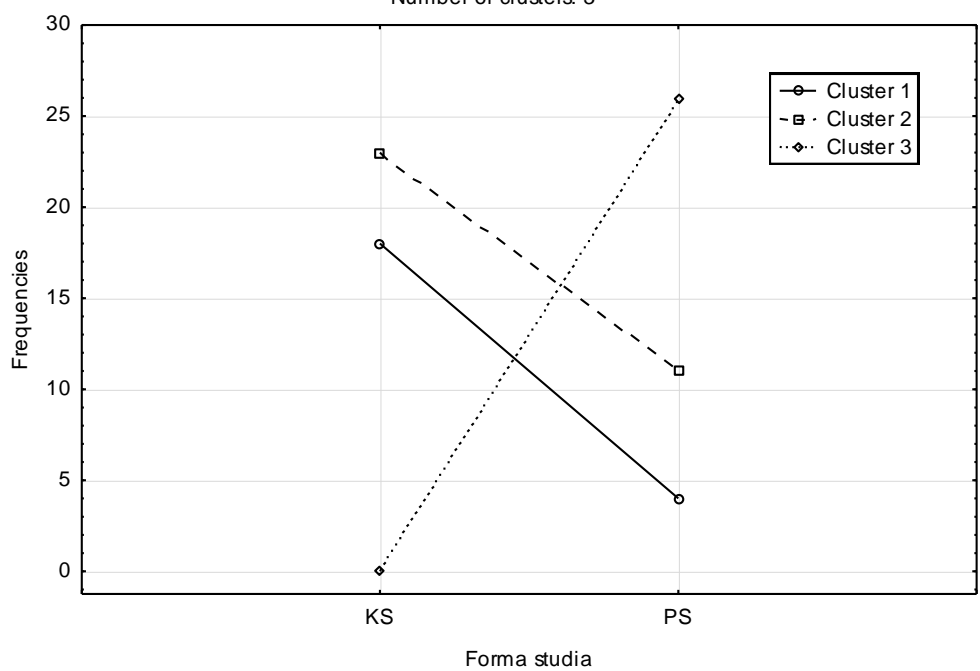

Graf č. 2: Analýza proměnné Forma studia podle př́slušnosti k jednotlivým shlukưm. 
Graph of frequencies for Preference učení z:

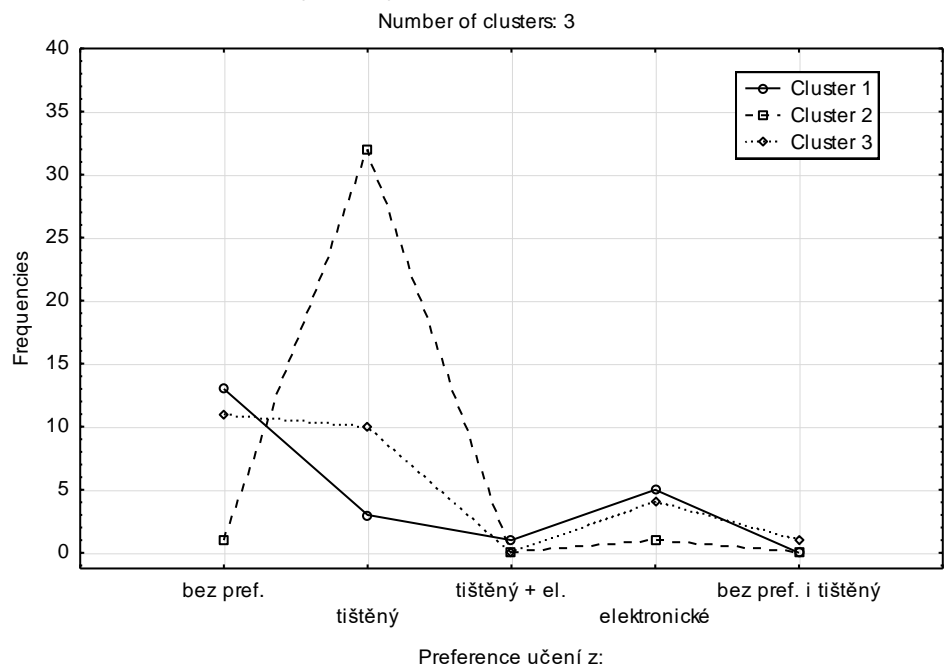

Graf č. 3: Analýza proměnné Preference učení podle př́slušnosti k jednotlivým shlukům.

Graph of frequencies for Setkali jste se selektronickými studijními materiály při studiu na VŠ či SŠ?

Number of clusters: 3

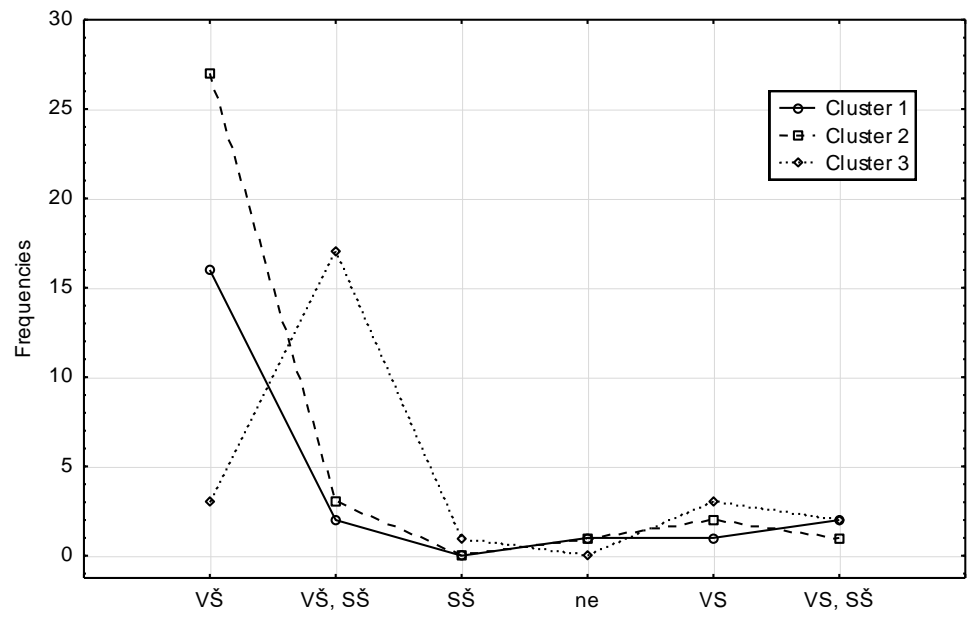

Setkali jste se selektronickými studijními materiály při studiu na VŠ či SŠ?

Graf č. 4: Analýza proměnné Setkali jste se s elektronickými studijními materiály při studiu na VŠ či SŠ podle př́slušnosti k jednotlivým shlukuim. 
Graph of frequencies for Chtěli byste dále ve studiu využivat elektronické studijní opory?

Number of clusters: 3

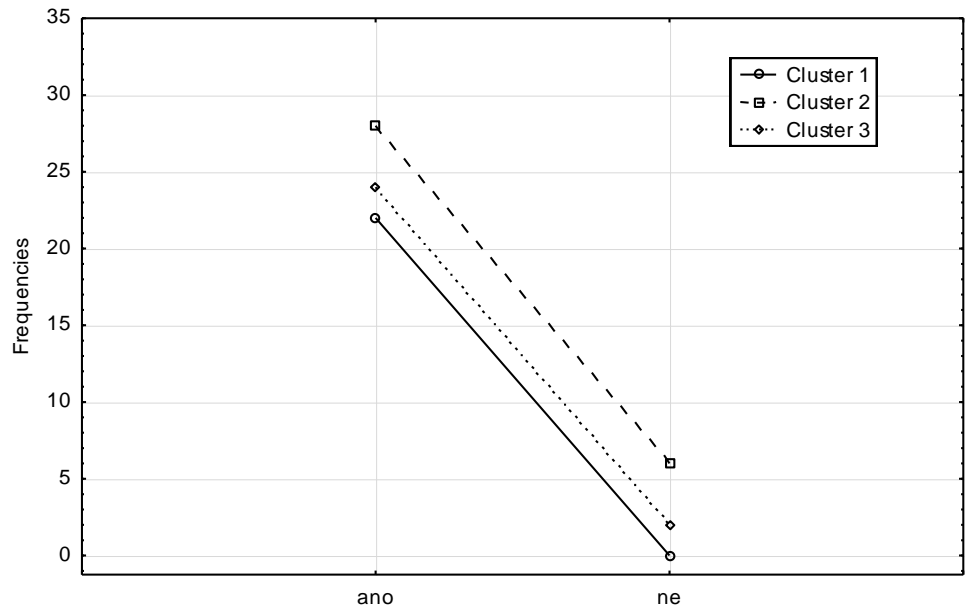

Chtěli byste v dále ve studiu využívat elektronické studijní opory?

Graf č. 5: Analýza proměnné Chtěli byste dále ve studiu využivat elektronické studijní opory? - podle přislušnosti k jednotlivým shlukům.

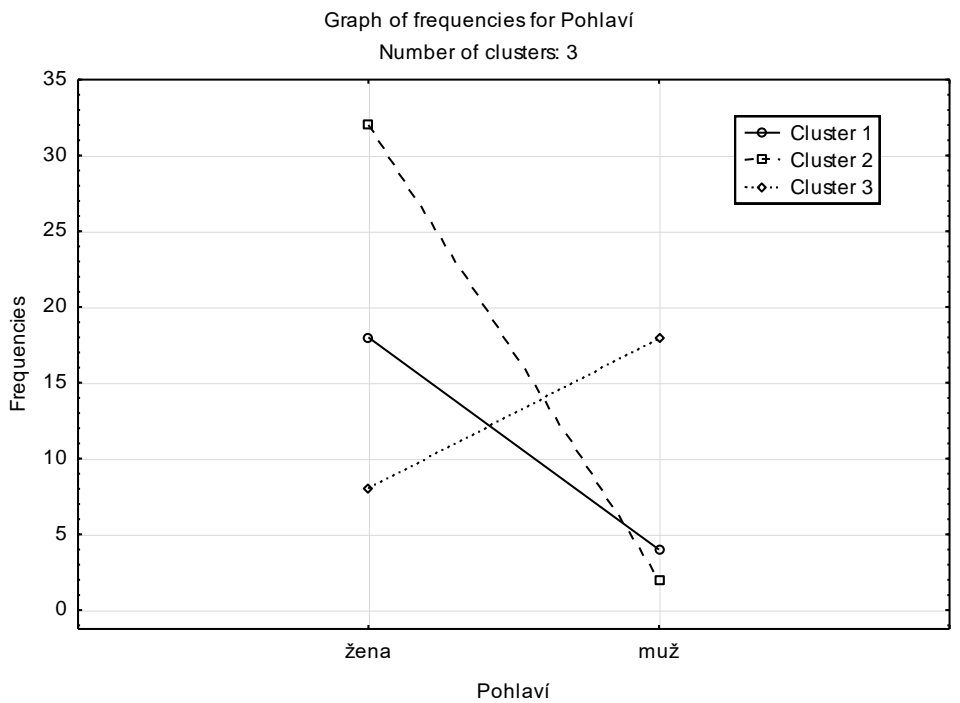

Graf č. 6: Analýza proměnné Pohlaví podle př́slušnosti k jednotlivým shlukům. 


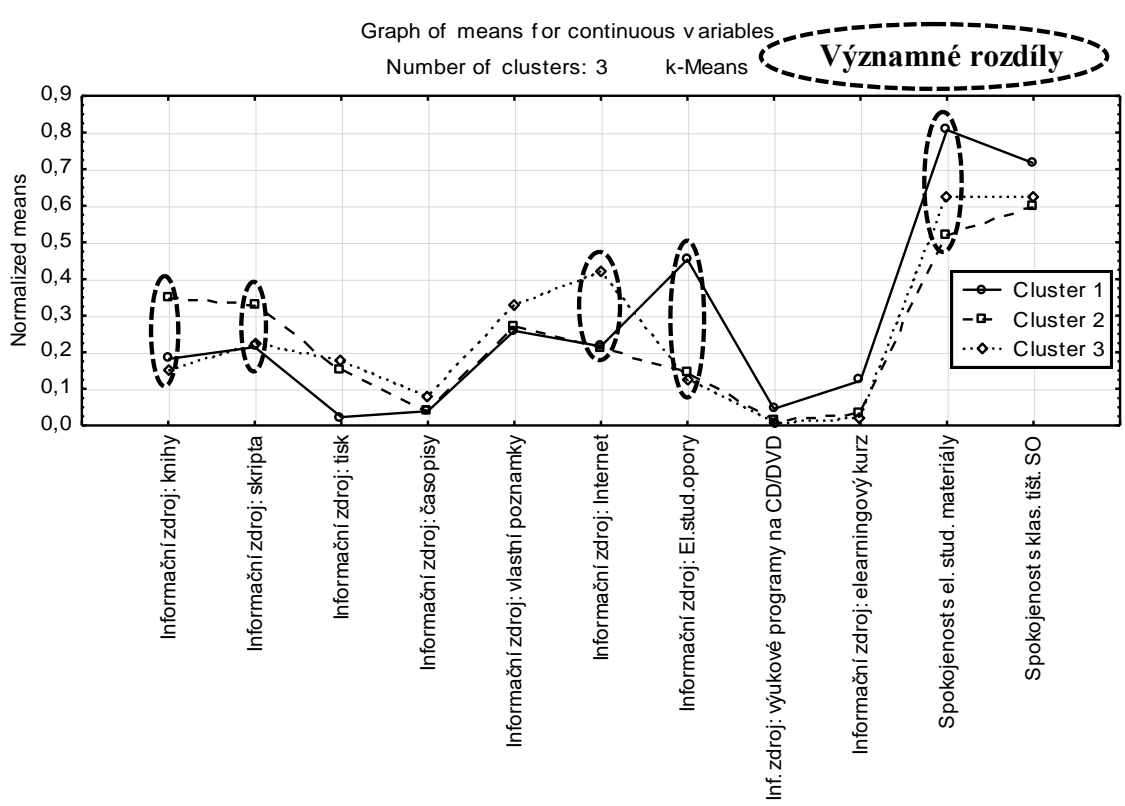

Variables

Graf č. 7: Analýza kontinuálních proměnných podle př́slušnosti k jednotlivým shluküm.

Na základě údajů uvedených v tab. č. 6 a grafech č. $1-6$ můžeme identifikovat typické vlastnosti studentů zahrnutých do jednotlivých shluků.

Shluk 1 - první shluk tvoří studenti, kteří oproti ostatním jako informační zdroj preferují nejvíce elektronické studijní opory a částečně Internet. Podle osobního názoru však nepreferují žádný typ studijních materiálů, i když jsou nejvíce spokojení s elektronickými studijními oporami, které by také všichni chtěli dále ve studiu využívat. Shluk tvoří $27 \%$ respondentů, je $\mathrm{v}$ něm zastoupena většina žen a studentů technického zaměření v kombinované formě studia.

Shluk 2 - druhý shluk tvoří studenti, kteří jako informační zdroj nejvíce používají knihy a skripta a částečně Internet, poměrně málo pak elektronické studijní opory, které by však chtěli dále ve studiu využívat. Téměř všichni také preferují tištěné materiály. Ve shluku převažují ženy. Shluk tvoří $41 \%$ respondentů, většinou humanitního zaměření (částečně také studenti K skupiny) v kombinované formě studia.

Shluk 3 - do třetího shluku patří studenti, využívající jako informační zdroj nejvíce Internet a částečně vlastní poznámky. Podle vlastního vyjádření však nepreferují žádné materiály, ale téměř všichni by chtěli dále ve studiu využívat elektronické studijní opory. S elektronickými studijními materiály se také již setkali při studiu na SŠ. Členy shluku tvoří převážně muži. Tento shluk obsahuje asi $32 \%$ respondentů převažujícího humanitního zaměření v prezenční formě studia. 


\begin{tabular}{|c|c|c|c|}
\hline $\begin{array}{l}\text { Výsledky pro shlukování metodou K-means } \\
\text { Počet shlukư: } 3 \\
\text { Celkový počet př́ípadů: } 82\end{array}$ & Shluk 1 & Shluk 2 & Shluk 3 \\
\hline Obor (převládající) & $T$ & $\mathrm{H}$ & $\overline{\mathrm{H}}$ \\
\hline Forma studia (převládající) & KS & KS & $P S$ \\
\hline Znáte pojem Elektronické studijní materiály? & ano & ano & ano \\
\hline $\begin{array}{l}\text { Setkali jste se se elektronickými studijními } \\
\text { materiály při studiu na V̌̆ či SŠ? }\end{array}$ & VŠ & VŠ & $V \check{S}, S \check{S}$ \\
\hline Preference učení z: & bez pref. & tišstěný & bez pref. \\
\hline $\begin{array}{l}\text { Chtěli byste dále ve studiu využívat elektronické } \\
\text { studijní opory? }\end{array}$ & ano & ano & ano \\
\hline Pohlaví (převládajicí) & žena & žena & muž \\
\hline Informační zdroj: knihy (\%) & 12,73 & 24,21 & 10,54 \\
\hline Informační zdroj: skripta (\%) & 17,14 & 26,12 & 17,88 \\
\hline Informační zdroj: tisk (\%) & 0,45 & 3,00 & 3,54 \\
\hline Informační zdroj: časopisy (\%) & 1,36 & 1,38 & 2,77 \\
\hline Informační zdroj: vlastní poznámky (\%) & 15,50 & 16,03 & 19,77 \\
\hline Informační zdroj: Internet (\%) & 19,45 & 19,15 & 37,77 \\
\hline Informační zdroj: el. stud. opory (\%) & 31,73 & 10,09 & 8,58 \\
\hline $\begin{array}{l}\text { Informační zdroj: výukové programy na CD/DVD } \\
(\%)\end{array}$ & 0,45 & 0,15 & 0,08 \\
\hline Informační zdroj: e-learningový kurz (\%) & 1,59 & 0,41 & 0,31 \\
\hline Spokojenost s el. stud. materiály (škála 1-5) & $\mathbf{4 , 2 3}$ & 3,09 & 3,50 \\
\hline $\begin{array}{l}\text { Spokojenost s klasickými tištěnými studijními } \\
\text { oporami (škála 1-5) }\end{array}$ & 3,86 & 3,38 & 3,50 \\
\hline Number of cases & 22 & 34 & 26 \\
\hline Percentage (\%) & 26,83 & 41,46 & 31,71 \\
\hline
\end{tabular}

Pozn.: Signifikantní rozdíly jsou označeny tučně a kurzívou.

Tab. č. 6: Zobecněná shluková analýza - typologie studentů podle využití informačních $z$ droju.

\section{Diskuse výsledků}

Oproti roku 2013 došlo u studentů PdF UP v prezenční formě studia k poklesu využití klasických informačních zdrojů jako jsou knihy a skripta celkem o $10 \%$, oproti tomu využití Internetu vzrostlo v roce 2015 o $9 \%$. Využití elektronických studijních opor přitom zůstalo stejné s celkem $7 \%$ podílem.

Co je však zajímavé, v roce 2015, kdy byly do výzkumu zahrnutí i studenti kombinované formy studia, byly zjištěny zásadní rozdíly ve využití informačních zdrojů u studentů PS a KS. Studenti KS podstatně více využívají elektronické studijní opory ( $21 \%$ oproti $7 \%$ ), což je pochopitelné, protože ty jsou pro ně primárně určeny. Více používají i knihy ( $25 \%$ oproti $10 \%$ ), avšak podstatně méně již Internet (17\% oproti $33 \%$ ), což je překvapivé a může to souviset např. s tzv. digitální propastí či odcizením (Zounek, 2006). 
Oproti roku 2013 mírně vzrostla spokojenost studentů s elektronickými studijními materiály $(3,45$ oproti 3,39$)$ a významně se snížila spokojenost studentů s klasickými tištenými studijními materiály $(3,35$ oproti 3,72$)$. I tak jsou však studenti s těmito materiály spíše spokojeni, protože jejich hodnocení na škále $1-5$ bylo v roce 20153,45 u elektronických studijních materiálů, respektive 3,35 u klasických tištěných studijních materiálů. Je však zřejmé, že využití elektronických studijních materiálů bude mít u studentů stoupající tendenci.

I v roce 2015 se podařilo prokázat, že studenti podle způsobu využití informačních zdrojů vytvářejí názorově tři odlišné skupiny. Vzhledem $\mathrm{k}$ tomu, že do zobecněné shlukové analýzy vstoupily i jiné proměnné, než v roce 2013, nemůžeme však oba výzkumy př́mo komparovat.

Oproti roku 2013 (Chráska, 2014) se však neobjevila skupina studentů - mužů, která by výrazně preferovala elektronické studijní materiály (tehdy shluk 3), studenti byli v tomto ohledu v roce 2015 spíše nevyhranění. Velká shoda však byla v obou letech ve shluku 2 , kde studenti výrazně preferovali klasické tištěné materiály a jednalo se převážně o ženy.

\section{Závěr}

$\mathrm{Z}$ provedeného, částečně komparativního, výzkumu vyplynulo, že př́istupy vysokoškolských studentů $\mathrm{k}$ využívání informačních zdrojů při jejich studiu jsou různé, stejně tak jako názory na preferenci jednotlivých typů studijních materiálů.

Obdobně jako v roce 2013 byly i v roce 2015 identifikovány tři typické skupiny studentů, které se zásadně odlišují svým př́stupem ke vzdělávání formou klasických tištěných studijních materiálů a formou elektronických studijních opor.

Bylo zjištěno, že skupina studentů, která v roce 2013 chtěla vzdělávání realizovat výhradně elektronickou formou, se již neobjevila. Určité „opojeni““, které bylo s touto formou výuky spojeno, tak již zřejmě opadlo a převládá realističtější pohled studentů. V roce 2015 se také ukázalo, že i když existují 3 názorově odlišné pohledy studentů na jednotlivé typy studijních materiálü, chtějí všichni studenti dále ve studiu využívat elektronické studijní opory.

Při realizaci vlastních e-learningových kurzů by se tak jejich autoři mohli zaměřit na studenty (respektive studentky) z identifikovaného shluku 2 (41\% respondentů), kteří jako informační zdroj nejvíce používají knihy a skripta a částečně Internet, avšak zatím poměrně málo elektronické studijní opory (i když by je použivat chtěli).

\section{Př́íspěvek vznikl $v$ rámci řešení projektu IGA_PdF_2015_009 „Identifikace vzdělávací strategie v MOOC kurzu u vysokoškolských studentů humanitního a technického zaměření“.}

\section{Literatura}

Baker, S. J. D. R. \& Yacef, K. (2009). The State of Educational Data Mining in 2009:

A Review and Future Visions. Journal of Educational Data Mining. 1(1).

Buckingham Shum, S., Ferguson, R. (2012). Social Learning Analytics. Educational

Technology \& Society, 15(3), 3-26. 
Fidalgo, P. (2012). Learning Networks and Moodle Use in Online Courses: A Social Network Analysis Study. Faculdade de Ciências e Tecnologia da Universidade Nova de Lisboa.

Hendl, J. (2004). Přehled statistických metod zpracování dat. Praha: Portál. Chráska, M. (2014). Approaches of University Students to Traditional and Electronic Study Materials - Results of Cluster Analysis. In Stoffová, V. XXVI. DIDMATTECH 2013 Educational Technologie in the Information- and Knowledge-Based Society. Brno: Tribun EU, s. 83-92.

Janská, L. (2013). Elektronické studijní opory a jejich hodnocení studenty Pedagogické fakulty. Trendy ve vzděláváni 2013. Roč. 6, č. 1. s. 220-225.

Juhaňák, L., Zounek, J. (2015). Analyzing Interaction Between Students In Online Discussion Forums Using Social Network Analysis. In ECER 2015: Education and Transition. Contributions from Educational Research, Corvinus University, 7.-11.9. 2015, Budapest, Hungary.

Klement, M., Chráska, M., \& Chrásková, M. (2015). The use of the semantic differential method in identifying the opininons of university students on education realized through e-learning. In The Proceedings of 5th World Conference on Learning, Teaching and Educational Leadership. Amsterdam: Elsevier (NL), s. 1214-1223. DOI

10.1016/j.sbspro.2015.04.165

Long, P. \& Siemens, G. (2011). Penetrating the Fog: Analytics in Learning and Education. EDUCAUSE Review, 46(5).

Meloun, M., Militký, J., \& Hill, M. (2005). Počitačová analýza vícerozměrných dat v príkladech. Praha: Academia.

Rabbany, R., et al. (2013). Collaborative Learning of Students in Online Discussion Forums: A Social Network Analysis Perspective. In Peña-Ayala, A. (Ed.): Educational Data Mining: Applications and Trends (pp. 441-466).

Reimann, P., Yacef, K., \& Kay, J. (2011). Analyzing Collaborative Interactions with Data Mining Methods for the Benefit of Learning. Computer-Supported Collaborative Learning Series, 12, 161-185.

Romero, C., \& Ventura, S. (2010). Educational data mining: A review of the state-oftheart. IEEE Transaction on Systems, Man and Cybernetics, part C: Applications and Reviews, 40(6), 610-618.

Siemens, G. (2012). Learning Analytics: Envisioning a Research Discipline and a Domain of Practice. International Conference on Learning Analytics \& Knowledge 2012. Siemens, G., Baker, R.S.J.d. (2012b). Learning Analytics and Educational Data Mining: Towards Communication and Collaboration. Proceedings of the 2nd International Conference on Learning Analytics and Knowledge.

Staudková, H. (2015). Způsoby využívání digitálních technologií vysokoškolskými studenty. Pedagogika, roč. 65, č. 3, 2015, s. 301-313.

Šarmanová, J., Kostolányová, K. (2015). Adaptive E-learning: From Theory to Practice. International Journal of Information and Communication Technologies in Education. roč. 2015, sv. 4, s. 34-47.

Zounek, J. (2006). ICT, digitální propast a vzdělávání dospělých: socioekonomické a vzdělávací aspekty digitální propasti v České republice. In Sborník prací Filozofické fakulty brněnské univerzity, Studia Paedagogica, U 11, Brno: Masarykova univerzita, s. $101-118$. 